嗨床実習において看護学生が看護上の判断に困難を感じる場面における指導者 の働きかけ

\title{
○布侉 真理子（聖路加看護大学大学院博士課程）
}

\section{はじぬに}

看護は一人一人異なった人間を扱い、また刻々と変化する文脈の中で繰り広げら れる。これは目の前の事態を認識し、評価、決断することが常に求められることを 意味する。従って、看護婦に求められる重要な能力の一つに判断力が挙げられる。 また看護を取り卷く状況の変化は、看護の立場から判断を下したり、調整のイニシ ヤティブをとって仕事を進みるといった必要性を生じさせている。このような理明 から、看護基礎教育において判断力の䏍成以重要なテーマとなっているが、臨床に おける判断を促進するような教育方法を論じた砳究は数が少なく、特にどのような 教育的アプローチが有效なのかは明らかにされていない。

本破究は、臨床実習において看護学生が看護上の判断に困難を感じる場面におい て、状況の理解や対処を助ける指導者（教員および臨床の指導者）の働きかけを学 生の認識から明らかにすることを目的とした。これにより実習指導の充実や、判断 力育成の教育を探究する一助となることを期待する。

\section{1. 研究方法}

1) 研究デザイン 質的記述的研究方法

2) 対象 首都圈の某大学看護学士諜程で学び、第 3 学年に在籍する看護学生であ り、研究への同意を得られた 12 名。健康障害を持つ成人を対象とする成人・ 老人看護学実兒に揖ける経験を語ってもらった。実習指導の体制は、教員が主 たる指導者であり、病棟看護婦が補助的に関わっていた。

3) データ収集と分析 半構成的面接法を用いた。面接内容は看護上の判断困難の の場面の内容と対処の状沉、指導者からの援助の内容とその受け止め方、その 後の状況の理解や対処の状況や帰結とした。実習期間終了後 1 週間以内に 60 分から90 分程度の初回の面接を実施し、承諾を得てテープレコーダーに録音し逐語 記録に起こした。得られたデータを判断困難の場面ごとに整理し、特に指導者 の働きかけと学生の反応に注目し、その意味をコード化し、比較しながら抽象 化した。また第一次の分析が終了した時点で、対象者全員に確認の面接を行っ た。一連のデータ収集および分析過程は研究指導者の指導のもとで行った。

\section{2 . 結果}

学生から語られた看護上の判断に困難を感じた場面は 32 場面であり、以下が明 らかになった。

1)臨床実習において、看護学生が看護上の判断に困難を感じる場面の内容には大き く3つのタイプがあり、それらは“患者への接し方” ‘看護のあり方” ‘患者と の関係の築き方’であった。

2)判断困難の状況の理解や対処の可能性が広がる働きかけとして、【学生の考えや 
経験を支持する】【状況を洞察することを助ける】【看護の進め方の判断材料を 提供する】ことが明らかになった。また、判断困難の状況の理解や対処が進展し ない働きかけとして、【学生の考えを尊重しない】【アドバイスがない】【結論 のみを指示する】ことが抽出された。これらは、それぞれ下位の要素を伴ってい た。

3)判断困難の状況の理解や対処を間接的に支える働きかけが存在し、それらは《学 生の関心事を把握し、継続的に関わる》《共に考える》《再考を促す》《カンフ アランスの場を提供する》《学生と患者の状況をよく知って関わる》《自分で取 り組む事を歓める》《現場のナースのフィードバック》であった。また判断困難 の理解や対処が進展しない働きかけを促進する働きかけとして、《消極的、否定 的に投げかける》《タイミングがずれる》《教員の不在》がみられた。

\section{3 . 考察}

明らかにされた指導者の働きかけを判断困難の克服との関連から考察を加える。 【学生の考えや経験を支持多る】働きかけは、自分の判断で以実施に踏み切るだけ の自信が持てない学生に、自信や安心感を提供し、学生が臨床状況に入り込んでい くことを促進し、実践の中で判断に厚みが加わっていくという相乗効果をもたらし ていた。【状況を洞察することを助ける】ことは、学生が患者をよく知ることを通 して、学生の判断を助けていた。【看護の進め方の判断材料を提供する】ことは、 指導者が日常的な学生との接触の場を大切にし、その中で学生に十分認識されてい ない視点を提供することであり、学生は自分の看護の方向ゔや方法についての示 唆を得ていた。

次に判断困難場面の状況の理解や対処の可能性が広がる場合と進展しない場合 に存在する、指導者と学生の相互作用の観点から分析を加える。学生の判断困難の 克服を助以る働きか以は学生の主体性を導く働きかけであるという特徵を共通に持 つていた。一方非效果的な働きかけは、結果的に指導者の判断が強調されていた。

あるいは判断困難の状況に関する学生一指導者閒の相互作用が不足していた。

以上より学生が自ら考え、行動することに洒值を置き、支持的に関わることの重 要性が示唆された。さらに、学生の臨床判断を刺激するのは、患者に関する学生間、 学生一指導者問の話し合いや、記録による臨床状況の振り返りであった。従って臨 休での出来事を言語化することを助け、継続的にフィ一ドバックすることが臨床に おりる判断を促進するとの示唆を得た。これは臨床状洗を説明する物語'narrative’ は、自身の関心、考え、感情を表明することによって、良いことへの気べきや考虑 されるべき文脈、関連する知識をもたらす1という主張と共通していた。

今回は第一段階として働きかけを受ける主体である学生の認識から看護上の判 断を助ける働きかけを明らかにした。従って指導者側の観点が含まれていないこと が本研究の限界である。今後はデータに指導者側の観点を加えた検討を行うことや、 教育課程や指導の体制、実㖬の領域におりる変動を把握していくことが課題となる。 引用文献 1)Benner,P. : Transforming RN Education: Clinical learning and clinical knowledge development, Transforming RN Education, “ NLN,Pub.No.14-2511,3-14,1993. 